\title{
DOES PRODUCT MARKET COMPETITION REDUCE AGENCY COSTS?
}

\author{
Ravi Jagannathan \\ Shaker B. Srinivasan \\ Working Paper 7480 \\ http://www.nber.org/papers/w7480 \\ NATIONAL BUREAU OF ECONOMIC RESEARCH \\ 1050 Massachusetts Avenue \\ Cambridge, MA 02138 \\ January 2000
}

We benefited from discussions with Phil Bromiley, Chun Chang, Espen Eckbo, and Sheridan Titman, as well as the participants at the Asymmetric Information Conference at the University of Minnesota, where an earlier version of this paper was presented. We are grateful for insightful comments from an anonymous referee. The usual disclaimer regarding any errors and omissions apply. The views expressed herein are those of the author and not necessarily those of the National Bureau of Economic Research.

(C) 2000 by Ravi Jagannathan and Shaker B. Srinivasan. All rights reserved. Short sections of text, not to exceed two paragraphs, may be quoted without explicit permission provided that full credit, including $\mathbb{C}$ notice, is given to the source. 
Does Product Market Competition Reduce Agency Costs?

Ravi Jagannathan and Shaker B. Srinivasan

NBER Working Paper No. 7480

January 2000

JEL No. L0, K0, G3

\section{ABSTRACT}

The folk wisdom is that competition reduces agency costs. We provide indirect empirical support for this view. We argue that the temptation to retain cash and engage in less productive activities is more severe for firms in less competitive industries. Hence an unanticipated increase in cash-flow due to higher past returns is more likely to lead to a reduction in leverage as well as a lowering of future returns for firms in less competitive environments. Current leverage will therefore be negatively related to past returns and positively related to future returns for such firms. In contrast, for firms in more competitive industries, the negative relation between past returns and current leverage will be attenuated. Theory suggests that the relation between current leverage and future returns for such firms will be zero or negative. Using a proxy to distinguish firms in less competitive industries and data for 165 single business firms in the U.S.A., we provide empirical supports for our arguments.

Ravi Jagannathan

J.L. Kellogg Graduate School of Management Northwestern University

2001 Sheridan Road

Leverone/Anderson Complex

Evanston, II 60208-2001

and NBER

rjaganna@nwu.edu
Shaker B. Srinivasan

Carlson School of Management

University of Minnesota

3-365

$32119^{\text {th }}$ Avenue $S$.

Minneapolis, MN 55455

balak001@tc.umn.edu 


\section{INTRODUCTION}

The popular belief is that competition decreases wasteful expenditures in corporations $^{2}$. Nichols (1996) shows that there is some empirical support for this belief ${ }^{3}$. Based on an analysis of U.K. companies, he concludes that the growth in factor productivity (which should be negatively related to corporate waste) is positively correlated with measures of competition. In this paper we provide some additional empirical support for this belief. We argue that the temptation to use free cash flow to reduce leverage and engage in less productive activities is more severe for firms in less competitive industries. Using data for 165 single business firms in the U.S.A. we provide empirical support for our arguments.

According to the neo-classical agency theoretic view of the firm, when investors employ agents to manage assets, agents will not in general behave in a way that is most beneficial to the principals, except to the extent such behavior is in their self interest. On the contrary, according to the more traditional view, managers behave as if they maximize the net present value of the firm.

The agency theoretic view that managers do not maximize value but preserve the value only because it is necessary for their survival dates back to Adam Smith, who had the following to say about joint stock companies in his treatise, "An inquiry into the nature and causes of the wealth of nations":

"The directors of such companies, however, being the managers rather of other people's money than of their own, it cannot well be expected, that they should watch over it with the same anxious vigilance with which the partners in a private copartnery frequently watch over their own. Like the stewards of a rich man, they are apt to consider attention to small matters as not for their master's honour, and very easily give themselves a dispensation from having it. Negligence and profusion, therefore, must always prevail, more or less, in the management of the affairs of such a company. It is upon this account that joint stock companies for foreign trade have seldom been able to maintain the competition against private adventurers. They have, accordingly, very seldom succeeded without an exclusive

\footnotetext{
2 The assumption is that the lack of shareholder power and other characteristics that leads to managerial slack due to the way the firm is organized remains the same across different firms.

3 Nichols (1996) based on his survey of the theoretical literature concludes, "....there are some theoretical reasons for believing this hypothesis, but they are not overwhelming."
} 
privilege; and frequently have not succeeded with one. Without an exclusive privilege they have commonly mismanaged the trade. With an exclusive privilege they have both mismanaged and confined it." (page 700 in the version edited by Edwin Cannan, Published by Random House Inc., 1937)

"The only trades which it seems possible for a joint stock company to carry on successfully, without an exclusive privilege, are those, of which all the operations are capable of being reduced to what is called a routine, or to such a uniformity of method as admits of little or no variation." (page 713, op. cit.)

Clearly, history has proved Adam Smith wrong in his prediction that the joint stock company will be a failure as an organizational form except in case of certain special types of businesses. This is because the modern day joint stock company is too complex to be described in terms of the master-servant relationship modeled in the neo-classical agency theory. For example, Fama (1980) has argued that modern day large corporations do not have owners in any meaningful sense. ${ }^{4}$ He views the corporation as having several constituents within a set of contracts called a firm. Shareholders, whom agency theory views as the owners of the firm, are just another group of participants in these contracts. Fama's hypothesis is that the firm as a whole is forced by competition from other firms to adapt devices for efficient monitoring of its activities. The individual members of the firm too are disciplined in the market for their services by competition from both within as well as outside the firm. This probably is the reason for the survival of the modern large corporation as a viable economic organization.

If Fama's view of the environment is right, then, for practical purposes, managerial decisions may well be close enough to decisions that would result if they were indeed maximizing the value of the firm. Clearly, not all managers of firms in the economy behave in this way. Jensen (1986) takes the opposite stand, that managerial behavior is better described by agency theory. He points out that when managers of firms are left with "free cashflow" that they can not employ productively in the firm's operations, it will be rather difficult for shareholders to force the managers to pay the cash out as dividends. Managers with access to such free cash flow will have a tendency to invest the cash in projects that yield below market return leading to organizational inefficiencies but result in personal gratification. Jensen gives the oil industry as an example where most firms within the

4 For convenience, we will refer to this view as Fama's views, although similar views are to be found in earlier literature. For an earlier exposition of this view, see Berle and Means (1932). 
industry experienced a large increase in cash flow due to events that took place in 1973 , while the same events required a down sizing of the industry as a whole. This created free cash flows with associated agency costs.

The oil industry example given by Jensen does not contradict Fama's conjecture since one could argue that competitive forces mentioned by Fama were not effective in the oil industry. As Jensen argues, take-overs appear to be the mechanism through which managers of such firms get disciplined. Of course, take-overs may consume substantial amount of resources and hence may be a costly mechanism and may not be as efficient as competitive forces, whenever such forces exist.

In this paper, we argue that for a sizable fraction of the modern day joint stock companies within an industry, competitive forces may be acting as a disciplining device. For such firms, the inefficiencies that arise due to the agency problem may be of second order importance. We empirically demonstrate that competition in the product market acts as a disciplining device in the following way.

A widely accepted tenet among the scholars of business strategy is that firms in the same industry may compete in very different ways. Case studies rich in details of diverse strategies pursued by competing firms, as well as evidence from more formal empirical investigations, lend support to this notion (Rumelt, 1991). Adopting this notion of heterogeneity among firms, we classify firms within an industry into two groups. Firms in the first group -- called specialists -- rely on their distinctive skills and resources to serve narrow market niches. In contrast, the second group of firms within the industry --called generalists -- are fairly similar to one another in terms of their skills, technology and product features. Suzuki of USA and BMW would be examples of specialists whereas Ford would be a generalist in this taxonomy. Specialist firms, to the extent they are successful in establishing market niches for themselves, are relatively immune from competitive market forces. The paucity of comparable firms complicates the task of separating poor managerial decisions, intentional or otherwise, from luck (or misfortune). In contrast, managers of generalist firms can be more easily compared with other generalists and therefore are more likely to be caught for misjudgments and self-serving investment decisions ${ }^{5}$.

\footnotetext{
5 A competing view-point for why "generalist" firms in competitive industries should have fewer agency problems may be due to the survival of the fit notion espoused in the literature. Specialist firms face less competition and hence persist in good or bad ways more easily. We thank the referee for pointing this out.
} 
We then show that managers of firms in the first group, when they have free cash flow, tend to put them to use as predicted by Jensen, i.e., their behavior is consistent with the predictions of the agency theory. Managers of firms in the second group behave as if they are maximizing the value of the firm. We argue that when managerial behavior is in accordance with Jensen's free cash flow theory, there is a positive relation between current leverage and future profitability whereas, the relation is negative if managers behave as though they maximize firm value. We provide empirical support for our arguments using data for single business joint stock companies for the period 1973 to 1990.

The rest of the paper is organized as follows. In Section 2, we develop the relation between financial leverage and profitability predicted by (a) agency theory and (b) value maximization theory of managerial behavior. In Section 3, we develop the econometric specification of the model, and describes the empirical results in Section 4. We conclude in Section 5 .

\section{RELATION BETWEEN FINANCIAL LEVERAGE AND PROFITABILITY}

Modigliani and Miller (1958) showed that financing choices are irrelevant for the firm's investment decisions, when capital markets are complete, function without friction, and all investors have the same information. Several scholars have since argued that a firm's leverage can affect the way the managers make investment and operational decisions because real world friction cannot be ignored as being second order in importance. For example, Jensen argues that there can be "agency benefits" to debt if it reduces free cashflow and thus restricts the scope of managerial discretion. Hence, leverage can be used to inhibit poor investment decisions by managers. Myers (1984) on the other hand describes how managers may have a preference ordering of financing choices even when they behave as though they are maximizing the value of the firm in the presence of taxes and private information with managers. We will use these two theories to derive the nature of the temporal relation between financial leverage and profitability. ${ }^{6}$ In what follow, we will refer

6 A number of papers have appeared in the theoretical corporate finance literature that study the interaction between a firm's competitive strategy in the product market and its choice of capital structure. Harris and Raviv (1991) classify models of capital structure that use the theory of industrial organization into two classes. Models in the first class examine the link between the firm's competitive strategy and capital structure. The first paper in this area is by Jensen and Meckling (1976) which pointed out that firms with large debt levels may have an incentive to follow riskier strategies. More recent papers include those by Brander and Lewis (1986), Allen (1985), Maksimovic (1986) Glazer (1989) and Glazer and Israel (1990), who study the relation between capital structure choice and product market strategy in an oligopolistic setting. Models in the second class are concerned with identifying product market characteristics that interact in a significant way with capital structure choice. Titman (1984) showed that high debt levels increase the probability of bankruptcy and hence impose a cost on customers who rely on the firm's ability to supply parts in the future (see also: Allen (1985) and John and Senbet (1988)). Maksimovic and Titman 
to Jensen's view as "the free cashflow theory" and Myers' view as "the pecking order theory".

Both the theories imply a negative relation between past profitability and current leverage. Hence they are both consistent with the observed negative correlation between profitability and financial leverage reported in Kester (1986), Baskin (1989), and Titman and Wessels (1988). Negative correlation between leverage and past profitability arises for the following reason when the free cash flow theory describes managerial behavior better. Suppose a firm earned above average return in the recent past. As Jensen (1986) points out, it is not easy for the share holders to motivate the managers to distribute this cash to the share holders. This retention of earnings will lead to an increase in equity and hence a decrease in financial leverage. According to the pecking order theory, wealth maximizing managers will prefer retained earnings to debt and outside equity for financing projects. Hence, so long as positive NPV projects are at hand, they too will retain earnings. This again leads to a negative relation between past profitability and current level of financial leverage.

While both theories have the same predictions for the nature of the relation between past profitability and current financial leverage, they have different predictions for the relation between current leverage and future profitability. According to the free cashflow theory, managers of firms with unanticipated excess cashflows tend to invest them in projects yielding returns below the cost of capital and waste it on organizational inefficiencies. This leads to a positive correlation between change in financial leverage and future profitability, since firms with free cash flows are more likely to be those which were lucky in the past to get large unanticipated cash inflows and retained them reducing their financial leverage. The pecking order theory assumes that managers maximize share holders wealth. Hence, other things being equal, they would retain a larger amount of cashflow (with resultant reduction in leverage) only if they have sufficient positive NPV projects. Firms which experienced a below average return in the past are able to identify positive NPV projects, are more likely to use debt to finance the projects. However, the cost of additional debt financing is likely to be much higher. This would lead to a negative relation between changes in financial leverage and future profitability. However, we may expect to find the negative relation to be weaker than that under the free cashflow theory,

(1988) show that firms that have to rely on their reputation in their product market may have to choose larger equity levels. How ever, this link has largely been ignored in the empirical corporate finance literature. A notable exception is Titman and Wessels (1988) who find that the uniqueness of a firms' assets is an important determinant of its capital structure. 
since, the negative correlation depends to a large extent on the magnitude of the cost of capital differential between debt and equity.

Jensen's free cashflow theory is relatively more relevant when the firm's managers choose to differentiate themselves from others within the industry by specializing their skills and resources to cater to (or use) particular niches in the market.

Its is difficult for the shareholders of specialist firms to identify firms engaged in similar activities for use as bench marks for comparative performance evaluation of the managers of such firms. Because of the difficulties associated with evaluating their performance, managers of such firms may also expect to get a relatively larger fraction of their compensation in deferred form depending on whether the firm is successful or not. Shareholders, when designing the compensation scheme, will also take into account the possibility that the managers have access to free cashflow. Even though from an ex ante point of view, managers who follow such a strategy will have to offer a competitive rate of return on investment to investors, ex post they are likely to have "free-cashflow" to waste. Hence, in such firms relative performance evaluation is not feasible. To the extent that other evaluation methods are not satisfactory, agency problems are likely to be more acute. ${ }^{7}$

If there is a way to identify the specialist firms, then we would observe the following pattern. Specialist firms which are relatively successful after start up will have relatively larger cashflow. They will retain this cashflow, which is also in accordance with the pecking order theory of capital structure, resulting in a relative decrease in current leverage. However, the retained cashflows will be used in projects yielding below market return. Hence future return and change in leverage will be positively related for such firms, which will be inconsistent with the pecking order theory.

As we pointed out earlier, specialist firms that rely on their unique positioning for success, can be expected to use custom designs, specialized equipment, and dedicated distribution channels as components of their overall business strategy. The extensive use of specialized resources can hinder their ability to adjust to environmental changes rapidly. Therefore, favorable events will lead to persistent profits and unfavorable events will lead to

7 When the economic environment is rapidly changing, time series data alone is unlikely to be of much help in assessing the performance of managers, and hence comparative performance evaluation is relied upon relatively often. Milgrom and Roberts (1992, p.221) argue that in general neither purely absolute nor purely relative performance evaluation is most efficient and that some mix of both of them will be the preferred choice. This does not contradict our view that comparative performance evaluation is unlikely to provide useful information if the manager of the firm follows a specialist strategy. Hence evaluating the performance of such a firm's manager is likely to be difficult. 
persistent losses. The generalists, who cater to the broad market, follow a more flexible strategy. They are more likely to use standard product designs, generalized assets, and mass distribution channels. Such firms are subject to relativ ely more severe competitive forces in the market place. Hence, the profits of generalist firms will be affected by chance event for relatively shorter duration when compared to specialist firms. We make use of these observations to identify specialist and generalist firms.

Generalist firms are more likely to resemble other firms following a generalist strategy. Investors can evaluate the performance of a generalist firm relatively more precisely by comparing it with the performance of similar firms in the industry. It will be possible to reward superior performance and punish inferior performance for such firms. It is reasonable to expect that managers of such firms will behave as if they are maximizing the wealth of share holders at all times.

As predicted by the pecking order theory of capital structure, generalist firms which were relatively more profitable in the past will have more cash to retain and hence will on av erage decrease their financial leverage. We should therefore expect to observe a negative relation between changes in financial leverage and future profitability. The negative relation will be stronger if managers of firms come with differing abilities and past performance reflects to some extent these differences.

It is convenient to write down these implications more precisely. Let $\mathrm{R}_{\text {it }}$ denote the date $t$ rate of return on assets employed by firm $i$ in industry $I$. We assume that $R_{\text {it }}$ has the following decomposition.

$$
\mathrm{R}_{\mathrm{it}}=\mu_{\mathrm{I}}+\delta_{\mathrm{i}} \mathrm{X}_{\mathrm{It}}+\mathrm{Y}_{\mathrm{it}}
$$

where $\mu_{\mathrm{I}}$ denotes the rate of expected rate of return on assets for firms in industry I, $\phi_{\mathrm{i}}$ denotes the expected firm-specific return, $\mathrm{X}_{\mathrm{It}}$ denotes industry specific shocks that affect realized return, $\delta_{\mathrm{i}}$ is the sensitivity of firm i to industry specific shock, and $\mathrm{Y}_{\text {it }}$ denotes firmspecific shocks. Both $\mathrm{X}_{\mathrm{It}}$ and $\mathrm{Y}_{\text {it }}$ are uncorrelated with each other, have a long run expected value of zero, but could be serially correlated. Let $\mathrm{DBA}_{i t}$ and $\mathrm{DBA}_{\mathrm{It}}$ denote the ratio of debt to book value of assets in place for firm i and industry I respectively. Then,

(A) $\operatorname{Var}\left(\mathrm{Y}_{\mathrm{it}}\right)>\operatorname{Var}\left(\mathrm{Y}_{\mathrm{jt}}\right), \delta_{\mathrm{i}}<\delta_{\mathrm{j}}$, and $\delta_{\mathrm{i}}, \delta_{\mathrm{j}}>0$, for firms $\mathrm{i}$ and $\mathrm{j}$ in industry I when $\mathrm{i}$ is a specialist and $\mathrm{j}$ is a generalist, where $\operatorname{Var}($.) denotes the variance operator. Therefore, it will 
be relatively more difficult to evaluate the performance of specialist firms than that of generalist firms.

(B) Suppose $\mathrm{i}$ and $\mathrm{j}$ denote two firms in industry $\mathrm{I}$, where $\mathrm{i}$ is a specialist and $\mathrm{j}$ is a generalist. Then $\mathrm{Y}_{\mathrm{it}}$ will be more persistent than $\mathrm{Y}_{\mathrm{jt}}$.

(C) Suppose $\mathrm{DBA}_{\mathrm{it}-1}$ is greater than $\mathrm{DBA}_{\mathrm{jt}-1}$ for two firms $\mathrm{i}$ and $\mathrm{j}$ in industry I. Then, (i)

$\mathrm{E}_{\mathrm{t}-1}\left(\mathrm{Y}_{\mathrm{it}}\right)>\mathrm{E}_{\mathrm{t}-1}\left(\mathrm{Y}_{\mathrm{jt}}\right)$, if both $\mathrm{i}$ and $\mathrm{j}$ are both specialist firms, and (ii) $\mathrm{E}_{\mathrm{t}-1}\left(\mathrm{Y}_{\mathrm{it}}\right)<\mathrm{E}_{\mathrm{t}-1}\left(\mathrm{Y}_{\mathrm{jt}}\right)$ if both $\mathrm{i}$ and $\mathrm{j}$ are generalists, where $\mathrm{E}_{\mathrm{t}-1}($ (.) denotes the conditional expectations operator based on information available at date $\mathrm{t}-1$.

(D) Suppose $R_{\mathrm{it}-1}$ is less than $\mathrm{R}_{\mathrm{jt}-1}$ for two firms $\mathrm{i}$ and $\mathrm{j}$ in industry I. Then DBA $\mathrm{it}_{\mathrm{i}}$ will be greater than DBA $\mathrm{jt}_{\mathrm{t}}$ irrespective of the strategy followed by $\mathrm{i}$ and $\mathrm{j}$.

\section{ECONOMETRIC SPECIFICATIONS}

In order to empirically examine the nature of the relation between capital structure and profitability implied by the two models of managerial behavior discussed in section 2 , we should be able to differentiate the specialist and generalist firms within each industry. Our discussion of the two strategies suggest that the profitability of specialist firms will exhibit relatively larger persistence [See (B) above]. We measure profitability by the average accounting rate of return on assets over some period. We also assume that persistence in profitability is measured, possibly with some error, by the first order serial correlation coefficient in return on assets. The use of first order serial correlation in accounting returns to classify the firm's strategic position in the market is not new (see Mueller (1986)). Let,

(1) $\quad R_{i t}=$ (profit before interest and taxes)/(total assets) -1

denote the date $t$ accounting rate of return on assets (not market return on investment) of firm i. Consider the first order auto-regressive representation of $\mathrm{R}_{\text {it }}$ given by:

$$
\mathrm{R}_{\mathrm{it}}=\lambda_{\mathrm{i} 0}+\lambda_{\mathrm{i}_{1}} \mathrm{R}_{\mathrm{it}-1}+\varepsilon_{\mathrm{it}}
$$


When $\lambda_{\mathrm{i} 1}$ is relatively large, shocks to returns tend to persist relatively longer. We estimate equation (2) for various firms using time series data and classify those firms within each particular industry that have less than industry average persistence as generalists. Those with above average persistence are classified as specialists. Let $\mathrm{DBA}_{\text {it }}$ denote the ratio of debt to total assets for firm $i$ at the end of period $t$. We use two measures of debt -long term debt and long term plus short term debt. This is because long and short term debt are close substitutes and theory does not provide clear guidelines regarding which one to use. Let $r_{i t}$ and dbait denote the corresponding terms measured as deviation from industry mean. Let,

$$
r_{i t, 5}=\left(r_{i t+1}+r_{i t+2}+r_{i t+3}+r_{i t+4}+r_{i t+5}\right) / 5
$$

Define dba ${ }_{i t, 5}$ analogously. Consider the following two cross sectional regressions.

$$
\begin{aligned}
& \mathrm{dba}_{\mathrm{it}, 5}=\gamma_{0}+\gamma_{1} \mathrm{r}_{\mathrm{it}-5,5}+\mathrm{v}_{\mathrm{it}+5}, \\
& \mathrm{r}_{\mathrm{it}, 5}=\beta_{0}+\beta_{1} \mathrm{dba}_{\mathrm{it}-5,5}+\mathrm{u}_{\mathrm{it}+5},
\end{aligned}
$$

In equation (4) we examine the relation between (a) the average debt to asset ratio (measured as deviation from industry mean) over the past five years and (b) the average return on assets (measured as deviation from industry mean) over the five years immediately preceding the period over which the debt to asset ratios are measured. We use five year averages to minimize errors that arise due to use of accounting numbers. For example, a firm may take an unusual one time charge that could depress its earnings in one particular year. The effect of such transactions will be weighted down when we use three year averages. The arguments in the earlier section imply that $\gamma_{1}$ will be negative for all firms.

In equation (5) we measure the cross sectional relation between current leverage (measured as deviation from industry mean) and expected future returns. Once again, we use the average leverage over the past five years instead of current leverage to minimize measurement errors. The arguments presented in the last section imply that we should expect to find a positive relation between future profitability and current leverage for firms operating in the noisy environment (high persistence firms). 
Firms that have relatively low leverage are those which had relatively high return in the past. Since high as well as low returns tend to persist, future returns will also be relatively high on average for those firms which have relatively low leverage now. If we ignore this effect, then we are likely to find a spurious negative correlation between leverage and future expected return. We control for this effect by including past return on assets as an additional explanatory variable, as in equation (5) below:

$$
\mathrm{r}_{\mathrm{it}, 5}=\beta_{0}+\beta_{1} \mathrm{dba}_{\mathrm{it}-5,5}+\beta_{2} \mathrm{r}_{\mathrm{it}-5,5}+\eta_{\mathrm{it}+5},
$$

We expect to find $\beta_{1}$ to be negative for generalist firms and positive for specialist firms, in equation (6). Notice that we are imposing the constraint that the effect of past return on future return is the same for all firms in the cross sectional regression. Hence, for firms that have larger persistence than the average firm, we would tend to under correct for the effect of past returns on future returns. For firms that have relatively lower persistence than the average firm, we would tend to over correct for the effect of past returns on future returns. However, there are no a priori reasons to suspect that this would bias the sign of $\beta$ in any particular direction.

To see this more clearly, consider a firm that had relatively large return in the past. The firm which has a relatively more persistent return process will tend to retain a larger amount of the cashflow. For such firms, we are under correcting for the effect of persistence, and hence such firms will show relatively larger return. This will tend to accentuate the negative relation between leverage and future returns. Hence in spite of this correction, we would still be biased against finding a positive relation between leverage and future profitability.

Measurement error (not taken care of working with five year averages) is another issue. If past returns are high due to measurement error, future returns are likely to low. This would cause a spurious positive correlation. However there are no a priori reasons to suspect that this would cause the nature of the correlation to be different between the two classes of firms.

\section{EMPIRICAL RESULTS}

\subsection{Description of data}


We limit attention to firms engaged in a single business activity in our study. This, we believe, enables us to control for noise by measuring variables as deviations from industry averages. We used information from SEC DISCLOSURE tapes (available in Spectrum CD ROMs) to identify firms with all the business activities falling into one 4 digit industry code in 1987. We then used the 1977 Million Dollar Directory (of Dunn and Bradstreet) to verify that the activities of these firms in 1977 was also limited to the same 4 digit SIC code industries. We will refer to these firms as single business firms.

Our basic source of data for these single business firms is from the Standard and Poor Compustat Full Coverage and PST tapes for the period 1973 to 1990 . The full coverage tape contains 2200 firms and the PST tape contains 770 firms, i.e., a total of 2970 firms. We limited attention to firms with continuous non-missing observations on Profits before interest and taxes, total assets, long term and short term debt for the period 1973-82. We also restricted attention to industries with at least 5 firms. This left us with only 165 firms.

\subsection{Discussion of results}

Table 1 presents the estimated values for parameters in equation (2) along with summary statistics on ROA on Long Term and Total Debt to Asset ratios. For all the 165 firms, the average persistence parameter is 0.51 . Note that we use only 10 years of data, the asymptotic standard error for the persistence parameter is 0.1 . The average value of the persistence parameter for the 81 firms in the high persistence category is 0.71 . The corresponding number for the 84 firms in the low persistence category is 0.31 . It is worthwhile stressing that we classify half the firms in an industry as high and the rest as low persistence. We do not attempt to partition the persistence measure into finer groups because the persistence parameter itself is measured very imprecisely.

As can be seen from Table 1, the average and the standard deviation of ROA, LD/A and TD/A for firms in the high and low persistence categories are not significantly different. Hence, these firms appear to differ mostly on the persistence dimension.

Table 2 gives the parameter estimates for equation (2). As we expected the estimated value of $\gamma_{1}$ is negative and significant when total debt to assets ratio is used as a measure of financial leverage for all firms as well as for firms in the high persistence environment. For the firms in the low persistence environment, the estimated value of $\gamma_{1}$ is 
not significantly different from zero. This is consistent with our expectation that the relation should be weaker for firms in the low persistence environment.

Table 3 gives the estimated values for the parameters of equation (5). The estimated value of $\beta_{1}$ is positive but not significant for firms operating in the high persistent environment. It is negative and significant for the low persistence environment. Hence the sign of slope coefficient $\beta_{1}$ are consistent with our expectations for both environments.

When lagged average return on assets is used to control for noise, we find that the slope $\beta_{1}$ in equation (6) is positive and statistically significant for the high persistence environment and negative and significant for the low persistence environment. These results are consistent with what we expected.

\subsection{Other proxies for business strategy}

In our study we used persistence as the measure of the firm's market power. We may conjecture that firms which use specialized facilities to appeal to particular segments of the market will be spending relatively more on R\&D, Advertisement, and Sales \& General Administrative Expenses (SG\&A). We therefore regressed R\&D and Selling expenses as a percentage of total sales (measured as deviations from industry mean) on persistence (measured as deviation from industry mean). The number of firms for which we had this information was 111 for R\&D, 105 for Advertising, and 175 for general administration expenses. The following table gives the correlation between persistence and the three other variables mentioned above with p-values in parenthesis.

\begin{tabular}{|c|c|c|}
\hline R\&D & Advertisement & SG\&A \\
\hline 0.14 & 0.03 & 0.00 \\
\hline$(0.40)$ & $(0.87)$ & $(1.00)$ \\
\hline
\end{tabular}

While the signs of all the correlation coefficients are what we would expect, they are not measured precisely enough.

\section{CONCLUSIONS}


We provide some empirical support for the view that competition reduces managerial slack. While our conclusions are similar to that reached by Nickell (1996), our methods are different. Nickel (1996) examines productivity directly. We argue that an unanticipated increase in cash flow due to higher past returns will lead to an unnecessary reduction in leverage and hence a lowering of future returns in less competitive environments. We present a method to distinguish firms in less competitive environments from those in more competitive environments and empirically show that the agency problem is more severe for firms in the former category. Our findings are consistent with the theoretical arguments in Jensen (1986) and Fama (1980). 


\section{REFERENCES}

Allen, Franklin, 1985, "Capital structure and imperfect competition in product markets", Working paper, The Wharton School, University of Pennsylvania.

Berle, A.A. and Means, G.C. The Modern Corporation and Private Property. New York: Macmillan, 1932.

Brander, James A. and Tracy R. Lewis, 1986, "Oligopoly and financial structure: The limited liability effect", American Economic Review, 76, 956-970.

Glazer, Jacob, 1989, "Live and let live: Collusion among oligopolists with long-term debt", Working paper, Boston University.

Glazer, Jacob and Ronen Israel, 1990, "Managerial incentives and financial signaling in product market competition", International Journal of Industrial Economics, 8, 271-280.

Fama, Eugene F., 1980, "Agency problems and the theory of the firm", Journal of Political Economy, col. 88, no. 2, pages 288-307.

Jensen, Michael C., 1986, "Agency costs of free cashflow, corporate finance and takeovers", American Economic Review, 76, 323-339.

Jensen, Michael C. and William Meckling, 1976, "Theory of the firm: Managerial behavior, agency costs, and capital structure", Journal of Financial Economics, 3, 305-360.

John, Kose and Lemma W. Senbet, 1988, "Limited liability, corporate leverage, and public policy", Working paper, Stern School of Business, New York University.

Lang, Larry, Annette Poulsen, and Rene M. Stulz, 1992, "Asset sales, leverage and the agency costs of managerial discretion", Working paper, College of Business, The Ohio State University.

Maksimovic, Vojislav, 1986, "Optimal Capital Structure in Oligopolies", Doctoral dissertation, Harvard University. 
Maksimovic, V. and S. Titman, 1991, "Financial policy and a firm's reputation for product quality", Review of Financial Studies, No.4, Vol.4.

Milgrom, Paul and John Roberts, 1991, Economics, Organization and Management, Prentice Hall, Englewood Cliffs, New Jersey.

Modigliani, Franco and Miller, Merton., 1958, 'Taxes and the cost ofcapital', American Economic Review, 53: 433-443.

Mueller, Dennis C., 1986, Profits in the Long Run, Cambridge University Press.

Myers, S.C., 1984, "The capital structure puzzle", Journal of Finance, 39: 581-582.

Nickell, Stephen J., 1996, "Competition and Corporate Performance", Journal of Political Economy, Number 4, Volume 104.

Rumelt, Richard., 1991, "How much does industry matter", Strategic Management Journal, 12: 167-185.

Smith, Adam, The Wealth of Nations, Edited, with an introduction, notes, marginal summary and an enlarged index by Edwin Cannan, The Modern Library, New York, Published by Random House Ine, 1937, page 700.

Titman, Sheridan, 1984, "The effect of capital structure on a firm's liquidation decision", Journal of Financial Economics, 13, 137-151.

Titman, Sheridan and Roberto Wessels, 1988, "The determinants of capital structure choice", Journal of Finance, 43, 1-19.

Williamson, Oliver, 1988, "Corporate finance and corporate governance", Journal of Finance, 43:567-591. 
TABLE 1

$$
R_{i t}=\lambda_{i 0}+\lambda_{i} R_{i t-1}+\varepsilon_{i t}
$$

\begin{tabular}{||l|l|l|l|l|l||}
\hline \hline Firm Class & Variable & Mean & StdDev & Min & Max \\
\hline \hline Low & $\lambda_{1}$ & 0.31 & 0.21 & -0.40 & 0.65 \\
Persistence & ROA & 0.10 & 0.04 & -0.04 & 0.20 \\
(generalist) & LD/A & 0.27 & 0.16 & 0.00 & 0.71 \\
$\mathrm{~N}=84$ & TD/A & 0.35 & 0.15 & 0.01 & 0.8 \\
\hline High & $\lambda_{1}$ & 0.71 & 0.14 & 0.40 & 1.06 \\
Persistence & ROA & 0.11 & 0.04 & 0.06 & 0.28 \\
(specialist) & LD/A & 0.26 & 0.17 & 0.00 & 0.53 \\
N=81 & TD/A & 0.31 & 0.16 & 0.00 & 0.60 \\
\hline All Firms & $\lambda_{1}$ & 0.51 & 0.27 & -0.40 & 1.06 \\
N=165 & ROA & 0.10 & 0.04 & -0.04 & 0.23 \\
& LD/A & 0.27 & 0.16 & 0.00 & 0.31 \\
& TD/A & 0.32 & 0.15 & 0.00 & 0.80 \\
\hline \hline
\end{tabular}


TABLE 2

$$
\mathrm{dba}_{\mathrm{it}, 5}=\gamma_{0}+\gamma_{1} \mathrm{r}_{\mathrm{it}-5,5}+\mathrm{v}_{\mathrm{it}+5}
$$

\begin{tabular}{|c|c|c|c|}
\hline Firm Class & $\begin{array}{c}\gamma_{0}(\mathrm{x} 100) \\
{[\mathrm{t}-\mathrm{val}]}\end{array}$ & $\begin{array}{c}\gamma_{1} \\
{[t-v a l]}\end{array}$ & $\begin{array}{l}\text { Adj. } R^{2} \\
\mathrm{x} 100\end{array}$ \\
\hline $\begin{array}{c}\text { All } \\
\text { LD/A }\end{array}$ & $\begin{array}{r}0.00 \\
(0.00) \\
\end{array}$ & $\begin{array}{c}-0.15 \\
(-1.16) \\
\end{array}$ & 0.21 \\
\hline $\begin{array}{c}\text { High Persistence } \\
\text { (specialist) } \\
\text { LD/A }\end{array}$ & $\begin{array}{c}-0.01 \\
(-0.97)\end{array}$ & $\begin{array}{c}-0.26 \\
(-1.85)\end{array}$ & 1.63 \\
\hline $\begin{array}{c}\text { Low Persistence } \\
\text { (generalist) } \\
\text { LD/A }\end{array}$ & $\begin{array}{c}0.01 \\
(0.36)\end{array}$ & $\begin{array}{c}0.06 \\
(0.28)\end{array}$ & -1.13 \\
\hline $\begin{array}{c}\text { All } \\
\text { TD/A }\end{array}$ & $\begin{array}{r}0.00 \\
(0.00)\end{array}$ & $\begin{array}{c}-0.28 \\
(-1.93)\end{array}$ & 1.63 \\
\hline $\begin{array}{c}\text { High Persistence } \\
\text { (specialist) } \\
\text { TD/A }\end{array}$ & $\begin{array}{c}-0.01 \\
(-1.58)\end{array}$ & $\begin{array}{c}-0.44 \\
(-2.78)\end{array}$ & 7.78 \\
\hline $\begin{array}{c}\text { Low Persistence } \\
\text { (generalist) } \\
\text { TD/A }\end{array}$ & $\begin{array}{c}0.01 \\
(0.69)\end{array}$ & $\begin{array}{c}0.03 \\
(0.12)\end{array}$ & -1.20 \\
\hline
\end{tabular}


TABLE 3

$$
r_{i t, 5}=\beta_{0}+\beta_{1} \mathrm{dba}_{i t-5,5}+\beta_{2} r_{i t-5,5}+u_{i t+5}
$$

\begin{tabular}{|c|c|c|c|c|}
\hline Firm Class & $\begin{array}{c}\beta_{0} \\
\text { [t-value] }\end{array}$ & $\begin{array}{c}\beta_{1} \\
\text { [t-value] } \\
\end{array}$ & $\begin{array}{c}\beta_{2} \\
\text { [t-value] } \\
\end{array}$ & $\begin{array}{c}\text { Adj. R-Square } \\
\mathrm{x} 100 \\
\end{array}$ \\
\hline $\begin{array}{c}\text { All } \\
\text { LD/A }\end{array}$ & $\begin{array}{c}0.00 \\
(0.00) \\
0.00 \\
(0.00) \\
\end{array}$ & $\begin{array}{c}-0.06 \\
(-1.03) \\
-0.00 \\
(-0.08)\end{array}$ & $\begin{array}{c}0.68 \\
(10.03)\end{array}$ & 0.04 \\
\hline $\begin{array}{c}\text { High } \\
\text { Persistence } \\
\text { (specialist) } \\
\text { LD/A } \\
\end{array}$ & $\begin{array}{c}0.01 \\
(1.81) \\
0.01 \\
(1.51) \\
\end{array}$ & $\begin{array}{c}-0.03 \\
(-0.28) \\
0.11 \\
(1.72) \\
\end{array}$ & $\begin{array}{c}0.81 \\
(10.11) \\
\end{array}$ & $\begin{array}{l}-1.16 \\
55.64\end{array}$ \\
\hline $\begin{array}{c}\text { Low } \\
\text { Persistence } \\
\text { (generalist) } \\
\text { LD/A } \\
\end{array}$ & $\begin{array}{c}-0.11 \\
(-2.01) \\
-0.01 \\
(-1.54)\end{array}$ & $\begin{array}{c}-0.06 \\
(-0.94) \\
-0.05 \\
(-0.89)\end{array}$ & $\begin{array}{r}0.49 \\
(4.49) \\
\end{array}$ & $\begin{array}{l}-0.15 \\
18.84\end{array}$ \\
\hline $\begin{array}{c}\text { All } \\
\text { TD/A }\end{array}$ & $\begin{array}{c}0.00 \\
(0.00) \\
0.00 \\
(0.00) \\
\end{array}$ & $\begin{array}{c}-0.11 \\
(-2.45) \\
-0.04 \\
(-1.07) \\
\end{array}$ & $\begin{array}{r}0.66 \\
(9.73) \\
\end{array}$ & $\begin{array}{r}2.95 \\
38.38\end{array}$ \\
\hline $\begin{array}{c}\text { High } \\
\text { Persistence } \\
\text { (specialist) } \\
\text { TD/A }\end{array}$ & $\begin{array}{c}0.01 \\
(1.77) \\
0.01 \\
(1.77) \\
\end{array}$ & $\begin{array}{c}-0.02 \\
(-0.31) \\
0.10 \\
(2.04)\end{array}$ & $\begin{array}{c}0.82 \\
(10.23)\end{array}$ & 56.30 \\
\hline $\begin{array}{c}\text { Low } \\
\text { Persistence } \\
\text { (generalist) } \\
\text { TD/A } \\
\end{array}$ & $\begin{array}{c}-0.01 \\
(1.70) \\
-0.01 \\
(-1.29) \\
\end{array}$ & $\begin{array}{c}-0.14 \\
(-0.05) \\
-0.11 \\
(-2.28) \\
\end{array}$ & $\begin{array}{r}0.46 \\
(4.33) \\
\end{array}$ & 23.01 \\
\hline
\end{tabular}

